NUMBER 3

NOVEMBER 2014

\title{
British Journal of
}
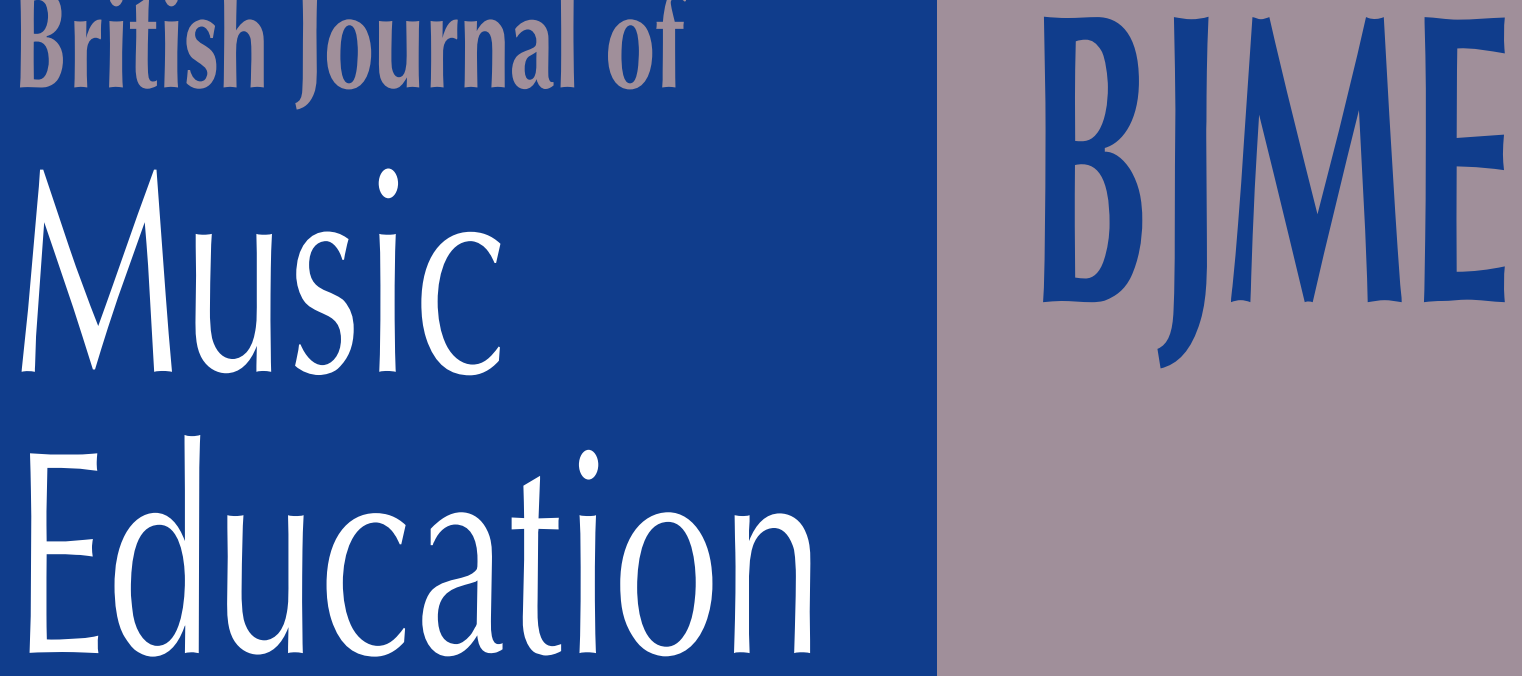

An International Journal 


\title{
BRITISH JOURNAL OF MUSIC EDUCATION
}

\section{Editors}

\author{
MARTIN FAUTLEY Birmingham City University, UK \\ REGINA MURPHY Dublin City University, Ireland \\ Book Review Editor \\ KAREN BURLAND University of Leeds, UK \\ Journal Administrator \\ CORMAC LAMBE Dublin City University, Ireland
}

\section{Editorial Board}

Birmingham City University, UK

JAMES BIDDULPH

London, UK

TIM CAIN

University of Southampton, UK

MARTIN CLOONAN

University of Glasgow, UK

GARETH DYLAN SMITH

Institute of Contemporary Music Performance, UK

KEITH EVANS

University of Greenwich, UK

JOHN FINNEY

University of Cambridge, UK

MARINA GALL

University of Bristol, UK

HELENA GAUNT

Guildhall School of Music \& Drama, UK

LUCY GREEN

University of London, UK

DIANA HARRIS

Open University, UK

JENNIE HENLEY

Institute of Education, UK

KATHRYN JOURDAN

St Mary's Music School, Edinburgh, UK

DEBORAH MAWER

Birmingham Conservatoire, UK

TIA DE NORA

University of Exeter, UK

OSCAR ODENA

School of Education, University of Glasgow, UK

JONATHAN SAVAGE

Manchester Metropolitan University, UK

IAN SHIRLEY

Edge Hill University, UK

HUGH SMITH

University of the West of Scotland, UK

GRAHAM WELCH

University of London, UK

VANESSA YOUNG

Canterbury Christ Church University, UK

SALLY-ANNE ZIMMERMANN

Royal National Institute for the Blind (RNIB), UK

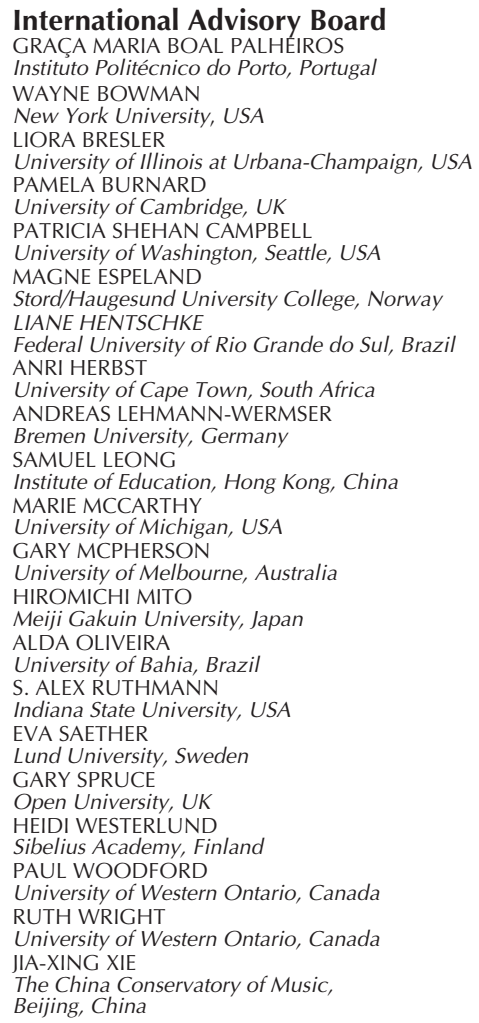

The British Journal of Music Education (ISSN 0265-0517) is a fully refereed international journal which aims to present clear and stimulating research on all aspects of music education. It is published in volumes of three parts in March, July and November.

Subscriptions: The subscription price which includes postage plus electronic access to institutional subscribers (excluding VAT) of volume 31, 2014 is $£ 199$ (US \$343 in USA, Canada and Mexico), $£ 46$ (US \$77 in USA, Canada and Mexico) print only for individuals and $£ 28$ (US $\$ 45$ in USA, Canada and Mexico) for students ordering direct from the Press and certifying that the journal is for their personal use. Single parts cost $£ 72.60$ net (US \$124.66 in USA, Canada and Mexico) plus postage. An electronic only price is available to institutional subscribers at $£ 172$ (US $\$ 293$ in USA, Canada and Mexico). EU subscribers (outside the UK) who are not registered for VAT should add VAT at their country's rate. VAT registered subscribers should provide their VAT registration number. Orders, which must be accompanied by payment, may be sent to a bookseller, subscription agent or direct to the publishers: Cambridge University Press, Journals Fulfilment Department, UPH, Shaftesbury Road, Cambridge CB2 8BS, UK. Orders from the USA, Canada or Mexico should be sent to Cambridge University Press, Journals Fulfillment Department, 100 Brook Hill Drive, West Nyack, NY 10994-2133. Periodicals postage paid at New York, NY, and at additional mailing offices. Prices include delivery by air. Japanese prices for institutions are available from Kinokuniya Company Ltd, PO Box 55, Chitose, Tokyo 156, Japan.

Copying: This journal is registered with the Copyright Clearance Center, 222 Rosewood Drive, Danvers, MA 01923. Organizations in the USA who are also registered with CCC may therefore copy material (beyond the limits permitted by sections 107 and 108 of US copyright law) subject to payment to CCC of the per copy fee of \$12. This consent does not extend to multiple copying for promotional or commercial purposes. Code 0265-0517/2014 \$12.

Organizations authorized by the Copyright Licensing Agency may also copy material subject to the usual conditions. ISI Tear Sheet Service, 3501 Market Street, Philadelphia, PA 19104, USA, is authorized to supply single copies of separate articles for private use only.

For all other use, permission should be sought from Cambridge or the American Branch of Cambridge University Press.

INTERNET ACCESS. This journal is included in the CJO service at journals.cambridge.org 